\section{International Scientific Journal Theoretical \& Applied Science}

p-ISSN: 2308-4944 (print) e-ISSN: 2409-0085 (online)

Year: $2016 \quad$ Issue: 9 Volume: 41

Published: $30.09 .2016 \quad$ http://T-Science.org
Vusal Hidayet Eminbayli

Ganja branch of Azerbaijan National Academy of Sciences,

Ganja, Azerbaijan

Elnur Tanriverdy Mammadov

Ganja branch of Azerbaijan National Academy of

Sciences,

Ganja, Azerbaijan

1-hasan@hotmail.com

SECTION 12. Geology. Anthropology.

Archaeology.

\title{
ABOUT INVESTIGATION OF HISTORICAL-ARCHITECTURAL HERITAGE OF GANJA BASED ON THE LOCAL SAMPLES
}

Abstract: In this scientific paper for the first time has been investigated the basic features of historic-cultural and architectural heritage of Ganja on the basis of scientific sources and materials as the multiculturalism sample.

Tolerance and multiculturalism is the state policy of Azerbaijan. The article examines of multiculturalism in the context of the contemporary globalizing world. The authors believe that the future of global society is impossible without the coexistence of different cultures, and tolerance and multiculturalism are the main principles of the new global society.

Also based on different historical sources, archive materials, manuscripts samples, various arguments and springs have been researched the main characteristics of historical development process of ancient cultural values of this old urban civilization center.

Key words: Ganja, Azerbaijan, archive materials, manuscripts, architecture, archaeology, ethnology, historical-cultural heritage.

Language: English

Citation: Eminbayli VH, Mammadov ET (2016) ABOUT INVESTIGATION OF HISTORICALARCHITECTURAL HERITAGE OF GANJA BASED ON THE LOCAL SAMPLES. ISJ Theoretical \& Applied Science, 09 (41): 66-70.

Soi: http://s-o-i.org/1.1/TAS-09-41-10 Doi: crossef http://dx.doi.org/10.15863/TAS.2016.09.41.10

\section{Introduction}

One of the main sample of historic-cultural and architectural heritage of Ganja is the Imamzada tomb-complex.

Architectural traditions of ancient and modern Ganja have an importance as the multiculturalism sample from the point of historic-cultural view. This city has more than 4000 years old and here there is one of the main and ancient historical monuments of Muslim East civilization - Imamzada tomb. This important monument is situated 7 kilometers from the city of Ganja, on the right shore of Ganjachai river.

Imamzade complex is one the main symbols of Ganja city and important example of medieval architecture of Azerbaijan. At the present time, as one of the most valued places of pilgrimage of the Islamic world, Imamzade tomb-complex in Ganja is a sacred place for local population, as well as pilgrims that come from different foreign countries.

Imamzade mausoleum, situated in one of the ancient scientific and cultural centers - Ganja State History-Culture Reserve, was built in 739 , on site of the grave of mevlana Ibrahim. Imamzade means "the descendant of imam," "from the family lineage of imam" [1, 11-16]

The historic monument of Ganja - Imamzade tomb-complex attracts the attention of a number of features from the point of multiculturalism view:

1. Ganja Imamzade is an important pilgrimage shrine. This place is visited by thousands of people every year. It should be noted that the number of visitors is increasing every year as well as foreign countries. Interesting fact is that non-Muslims are also among that memorial.

2. The mausoleum, built around the grave of mevlana Ibrahim in the VIII century, was enlarged in the XIV-XVI centuries, and subsidiary buildings around it were erected in the XVII-XVIII centuries. The tomb is the most important part of the Imamzade complex. The height of the dome of tomb building is $12 \mathrm{~m}$, the height of cupola is $2.7 \mathrm{~m}$ with diameter of $4.4 \mathrm{~m}$, covered with blue tiles. Another designation for Imamzade, also known as the Goy (Blue) Imam Turbe, according to different sources can be related to ancient belief of the Azerbaijanis to Goy Tanr1, from whom the Turkic dynasties claimed to be descended. 
3. Ganja Imamzade is a very valuable, ancient epigraphic monument. The inscription on the monument of great importance and recordings are available.

4. This historical monument is an important source of investigation of traditional ethnographic view of the valuable of Azerbaijan people, national and moral values.

5. Ganja Imamzade complex has a very refined, high-quality craftsmanship and architecture features, combining of this complex.

6. The area of Imamzade complex was included in the property of the Sheykhzamanlis - the descendants of Nizami Ganjavi, the great Azerbaijani poet and philosopher. Through the centuries, people carried and protected this sacred site. Ganja Imamzade have the value as an important source of research of the genealogical history of the people. Thus, as a result of the analysis of ancient manuscripts and historical documents it was determined that, a prominent thinker and poet Nizami Ganjavi (1141-1209), as representatives of the owners of the private land owner of the monument over the long term and their graves have been preserved to this day in the cemetery near the monument Imamzade.

7. Ganja Imamzade complex also has been known for years as the shelter, that helped lonely people, people living in poor conditions, or facing sickness and homelessness. Subsidiary buildings of Imamzade complex were used as an orphanage during former Soviet reign in 1930-1944s. This sacred place became a shelter for the little children from various ethnic backgrounds who suffered in the World War II. Nowadays, the members of different religions still come to pay their respect to this holy place. The valuable experience of Azerbaijan in the sphere of interreligious dialogue and cooperation has been highly appreciated and is well-known to everyone in the world.

8. This is an example of valuable historical and architectural importance of the Western region of country, characterized by religious monuments in terms of tourism development. Reconstruction and renovation works carried out now will be further increased the value of this monument in the future for development of this important sector - tourism.

\section{Materials and Methods}

One of the basic materials for this research is the traditional craftsmanship.

a) Wool waving was one of the main areas of weaving. Sheep farming made up the main raw material base of wool weaving. In Ganja carpetweaving formed as one of the widespread sector of wool weaving and handicraft, generally. The majority of women of Ganja and its regions got busy with waving and their carpets were distinguished with their brightness and robustness. According to the sources, hundreds of handicraft enterprises had engaged in the production of carpets in the third quarter of the nineteenth century. In addition to this, one thing should be noted that that the carpet has gone through several stages in its development. Matting which are considered as first tissue material were knitted with hemp and cane. Later, simple rugs have been occurred, following that colorful and embroidered rugs, then zili, verni and sumach. In the last stage, fleecy carpets were knitted with a complicated pattern. Fleecy products were divided different species according to its form and size, such as: carpet, rug, prayer mats moreover, without pile carpets are classified due to its production techniques and the purpose of utilization: palaz(kind of carpet without pile), verni, sumach, ladi, saddle-bag, horsecloth, holdall, sack, pouch, salt bag etc. Among them palaz hold special place was related to its daily importance. Palaz divided into two groups: Saya (plain) and patterned. Sayapalaz knitted as striped and without striped, patterned knitted like tayuzlu.

b) Generally, during the exploring of weaving artit is important to touch on the condition of mastery neigborhoods which are the units of essential townbuilding. In this period, Sharbaglar and Boyagchilar which had already been independent, were created like streets and gradually was a part of neighborhood Imamli, in the frontier of the eighteenth and nineteenth century.

In research of problem of multiculturalism has so great significance heritage of genius persons as poets, thinkers.

c) Nizami was a genius who projected his humanism beyond national borders, as clearly evidenced by his choice of main characters of his masnavis. His hero can be Persian, Arabian and Greek. The aim of Nizami is not captured by the nationality of the hero or character. The purpose is to find the supreme literary solution of the idea. However, neither the choice of main characters nor the reperesentation of dozens of nationalities throughout his poems is unintentended. Nizami does so inientionally. Thus he once more demonstrates that he writes about and for human beings, and that the readers of his works should be not one nation but many nations. And consequently it happened exactly that way. Nizami is one of the most wiedly-translated classics in the world. What's more, ever newer languages will join the ranks of these languages. Through his works Nizami not only founded a literary pattern to be repeated over centuries, but also the pattern for building ideas, nations, morality and states.

d) The ideals which Nizami propagated eight centuries ago remain desirable today. Humanity is presently fighting for domination of the features Nizami wished to see human beings and society. The city Nizami depicts in his final poem - in "Iqbalname" part of "Iskandername" actually was the 
society he dreamt of and wished to see implemented. Along with other world genius who served a kind of global school, Nizami has clear stake in the overall progress attained by mankind from Nizami's time until now.

In this city all are equal, while respecting human rights is a bedrock societal norm. Money has already been abolished. There are no police either, rendered obsolete by the absence of legal violations in this conscientious and disciplined society.

e) We have not yet attained Nizami's desired world or the above-mentioned days. Nevertheless, humanity has always longed for such happy life, both eight centuries ago and millennia goneby. Therefore, there is today, and will remain tomorrow, the need for the light of Nizami's word and candle.

f) Each compatriot of Nizami - each Azerbaijani-is in need of this light. Each compatriot of Nizami - each resident of earth and each citizen of the world - is in need of this light. Nizami Ganjavi, a person embodying the wishes of everyone, belongs to all. He is eternal because he belongs to everyone. Nizami will always be one step ahead of us, navigating towards a serene future.

By the way, the heritage of Nizami Ganjavi, especially his poems with different scientifichistorical facts and arguments have so great importance as the indisputable sources in research of various aspects in investigation of such academic themes as legal culture and its historical review, also basis of multiculturalism traditions in Ganja and the whole Azerbaijan.

\section{Conclusion}

Handicraft traditions of Ganja city is one of the basic characteristics in investigation of urban culture, multiculturalism and tolerance features.

In the research stage of Ganja, carpet weaving was particularly notable in the field of weaving. Without pile carpets that belonged to different areas although had same style but they were distinguished from others with artistic characteristics, colour and patterns. When were knitted without pile carpets in that time, sheep and cave wool made utilized as raw material.

In Ganja and other cities, have been used not only wool, but also cotton and silk, silver and gold helves, even precious stones. At the end of XIX early XX century without pile carpets, palaz and "cecim" were widespread. Tightly woven wool products Cecim played an important role in the daily life of every Muslim family. Women knitted cecim for themselves and even for their daughters as dowry. With wool and silkcecim case, face blanket, face couch, face pillow, face bolster, curtains, saddle, saddle-bags and mattresses were made too. In the nineteenth century, the majority of women were involved in carpet and palazweaving furthermore, they earned enough.
1. Carpets and palaz were weaved in a long run and it was so complicated, that is why, these aspects were influenced on their prices. The prices of t carpets were 3-4 chevrons up to 18 chevrons, or from 3-4 silver to 7 silver. Thus, for the carpets this was $4 \mathrm{~m}$ length, 2.5 width had to 2 pood wool. Kilim (tapestry-woven type of rug)which included kind of without pile carpets differed from each other, depending on its area. For them have been used repeated different geometric components decorated with thick and thin horizontal lines. Zili had a special place among without pile carpets. The zili of Ganja was distinguished by its composition and colors. In these zili were reflected geometric elements such as birds, buta, and rhombus without pile carpets shadde, verni and sumakh also were an interesting due to their technology features. Shadde has been used in order to both hanging on the wall and lying down as cover.

2. Usually there were camel caravans, people and domestic animals descriptions. Verni and sumakh that include without pile carpets more widely used in Ganja compare with Baku and other cities. Elm, walnut leaves, red sandalwood, pomegranate peel, onion peel and other plants and herbs have been used for painting yarns and ready products in Azerbaijan. In Ganja dyeing has been developed in the same way. In addition to the above-mentioned dyeing substances, also mineral substances, swampy clay, wood ash, salt, alum and major cattle urine had been used as an auxiliary means. It should be mentioned that the auxiliary items were divided into two groups according to the period of operation, some of them used to paint before (alum, lavashana etc.), whereas others carried out a duty as strengthen and change the color of dye.

3. Divided into two parts for the quality of dyes, dyes consisted of properties and practical. Natural colors has been used for knitting the yarns of carpets which were domestic demand or order, practical dyes has been used for market products. By the middle of the nineteenth century, natural dyes made utilized in Ganja. Even any woman who didn't work as a dyer could get natural paint from plant, fruit leaves that were within arm's reach. After the discovery of artificial coloring matters mostly, products were painted through artificial colors.

4. At this point it is necessary to mention some characteristic features of dyeing, which is an integral part of a weaving. Thus, technological process of dyeing divided into three phases and the first phase was the collection of dye plants and the correction of paint fluid.

5. In the second phase of the material prepared for dyeing, the strengthening of color belonged to the third phase. The quality of wool was very important role in dyeing. So, for waving, etched from the waist part of sheep were considered as better quality in spring clipping. For the preparation of this product, 
wool was selected, was washing with substance which was prepared from grass ash and was growing on the ground. Washing with cold water, was giving the softness and shimmer that ensured to store suet in the content of water. Yet, it was influenced on the quality of paints, negatively. Obtaining pigment substance, it means that the preparing of pigment substance was necessary in the field of dyeing.

6. Usually, paint plants were collected in spring and autumn. In the light of this reason, in that period were obtained colorful paints from collected plants. Some of them have been used as desiccated, the rest of them as natural case. During the painting process, yarns were boiled together with paint plants or firstly, dye solution was prepared. Then the solution was released into the same yarn. Prior to that alum or sour plum mixed with alum included the solution which prepared from lavashana. If they were not anylavashana in that case rub or buttermilk has been used instead of lavashana. Dyeing process was carried out in specially designated places. Local people called these places as dye-works or kupxana. It is necessary to mention that dye-works and kupxana differed from each other.

7. For the first time has been investigated the basic features of historic-cultural and architectural heritage of Ganja on the basis of scientific sources and materials as the multiculturalism sample. The article examines of multiculturalism in the context of the contemporary globalizing world. The authors believe that the future of global society is impossible without the coexistence of different cultures, and tolerance and multiculturalism are the main principles of the new global society [22, 133].

8. Also based on different historical sources, archive materials, manuscripts samples, various arguments and springs have been researched the main characteristics of historical development process of ancient cultural values of this old urban civilization center in Ganja.

\section{References:}

1. Ohmədov FM (2007) Gəncənin tarix yaddaş1. Gəncə: Elm.

2. Hasanov EL (2016) Innovative basis of research of technologic features of some craftsmanship traditions of Ganja (On the sample of carpets of XIX century). International Journal of Environmental and Science Education, 11(14), pp. 6704-6714.

3. (1648) Khamsa of Nizami. "Khosrov and Shirin" Bukhara (Moscow, SPL, NPV, 66).

4. (2008) Azərbaycan arxeologiyas1, 6 cilddə, VI cild. Bakı: Şərq-Qərb nəşriyyatı, 632 p.

5. (2007) Azərbaycan etnoqrafiyası: 3 cilddə, I cild, Bak1: Şərq-Qərb, 544 p.

6. Guliyeva NM, Hasanov EL (2013) Investigation of basic decorative-applied arts of Ganja on the basis of some innovative arguments and technologies. Science and Society: Proceedings of the 3rd International scientific-practical conference. London, pp. 281-291.

7. Guliyeva NM, Hasanov EL (2014) Die traditionelle Gändschänischen Teppiche von Zeitraum der Aserbaidschanischen Gelehrten und Dichter Mirsä Schäfi Waseh als ethnoanthropologische quelle (XIX Jahrhundert). European Applied Sciences, 2, pp. 3-5.

8. Həsənov EL (2012) Gəncə İmamzadə türbəsi (tarixi-etnoqrafik tədqiqat). 1-ci nəşr. Bakı: Elm və təhsil, $268 \mathrm{p}$.
9. Hasanov EL (2014) Innovative basis of research of local handicraft branches of Ganja of the second half of XIX - beginning of XX centuries. Mediterranean Journal of Social Sciences, vol. 5, № 23, Part IV, pp. 2359-2362. Doi:10.5901/mjss.2014.v5n23p2359

10. Ofəndiyev RS (1976) Azərbaycanın dekorativtətbiqi sənətləri. Bakı: İşıq.

11. Gəncənin məhəllə adları (1978) Elm və həyat jurnal1, №10.

12. Hasanov EL (2015) Multidisciplinary approach to investigation of the basic handicraft branches of Ganja till the XX century. ISJ Theoretical \& Applied Science 1(21): 7-15. DOI: http://dx.doi.org/10.15863/TAS.2015.01.21.2

13. Hasanov EL (2015) To the Question on Research of Craftsmanship Traditions of Ganja of XIX - First Half of XX Centuries. Mediterranean Journal of Social Sciences, vol. 6, № 1, Part S1, pp. 433-437. Doi:10.5901/mjss.2015.v6n1s1p433

14. Həmidova I (2000) Azərbaycan parça sənətinin tarixi inkişaf yolları. Elmi axtarışlar, VIII toplu, Bak1.

15. Həsənov EL (2015) Gəncə İmamzadə türbəsi ənənəvi multikulturalizm abidəsi kimi. Qafqazda mədəni-dini irsin qorunması mövzusunda beynəlxalq konfransin materialları. Bak1, 2015, pp. 117-120.

16. Gasanov EL (2015) Ob innovatsionnykh rezul'tatakh istoriko-etnograficheskogo 


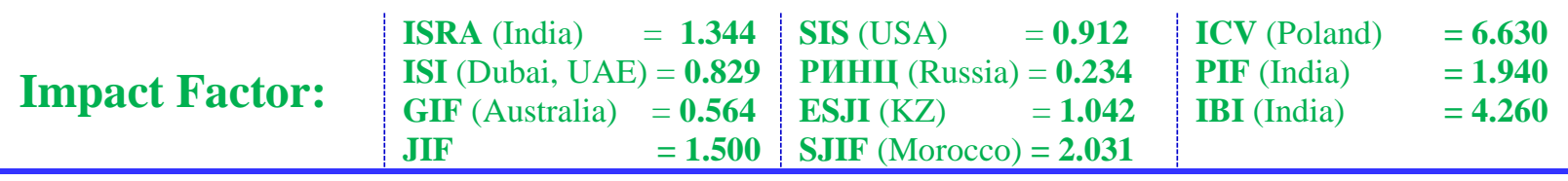

issledovaniya khudozhestvennoy keramiki drevney Gyandzhi. Novyy universitet Aktual'nye problemy gumanitarnykh i obshchestvennykh nauk. № 8-9 (53-54). DOI: 10.15350/2222-1484.2015.8-9.

17. Məmmədov FN (1976) XIX əsrdə Gəncə şəhərinin ərazisi, əhalisi və idarəsi (1868-ci ilə qədər). Azərbaycan SSR Elmlər Akademiyasının Xəbərləri (Tarix, fəlsəfə və hüquq seriyas1), №3, pp. 30-37.

18. (1974) The dawn of Art Leningrad: Aurora Art Publishers, $196 \mathrm{p}$.

19. Burton-Brown $\mathrm{T}$ (1951) Excavations in Azerbaijan, 1948. London, 1951.
20. Stern SM (1960) The Early Ismaili Missionaries in North - West Persia and in Khurasan and Transoxania. Bulletin of the school of Oriental and African Studien. University of London, 1960, 23/1.

21. Hasanov EL (2014) Approccio innovativo per lo studio scientifico delle tradizioni artigianali grandi Ganja seconda metà del XIX-inizi XX secolo. Italian Science Review, 2014, 4 (13).

22. Kulieva NM, Gasanov EL (2011) O razvitii khudozhestvennoy keramiki v drevney Gyandzhe // Voprosy obshchestvennykh nauk: sotsiologiya, politologiya, filosofiya, istoriya.: sb. materialov Mezhdunar. nauch. konf. Novosibirsk: Apriori, pp. 132-135. 